\title{
RANCANGAN CITY BRANDING KOTA PADANG \\ PENTINGNYA SEBUAH BRANDING DALAM PERKEMBANGAN KOTA
}

\author{
Haris Satria \\ Dosen Jurusan DKV, Univ. Putra Indonesia YPTK Padang, \\ Dekan Fakultas Desain UPI YPTK Padang \\ Email: harissatria89@gmail.com
}

\section{ABSTRACT}

The final work is titled Draft City Branding Padang city. The introduction has not been packaged properly. It creates an image that is less attractive for tourists, when in fact the City The potential that ought to be proud of by the people. This design uses the theory of city branding, communication theory, design theory and the theory of color. Therefore, in the design of this time are highlighted in The later through verbal and visual messages, tagline and media applications that are effective and efficient.

As for media design is the logo along with the explanation. Design a billboard media applications, facebook account, $t$-shirts, mugs, keychains, signed area, posters, pins, post card, sticker, calendar and flaxchange. All the media is part of the process of city branding Padang city.

Keywords: Concept, City Branding, Padang.

\section{Pendahuluan}

Kota Padang adalah ibukota Provinsi Sumatera Barat yang merupakan kota pantai yang indah dan nyaman. Kota Padang merupakan pintu gerbang utama wisata pantai barat pulau Sumatera. Objek wisata dan produk tradisional yang ada di Padang pada dasarnya tidak kalah menarik bila dibandingkan dengan kota-kota wisata lainnya di Indonesia. Semua yang ada dan tampak merupakan aset terbaik dari Kota Padang.

Padang banyak memiliki tempat-tempat yang sangat menarik dan potensial, seperti: Pantai Padang, Gunung Padang, Taman Siti Nurbaya, Pantai Air Manis, Pantai Pasir Jambak, Pulau Sikuai, Taman Raya Bung Hatta, Lubuk Paraku, Lubuk Minturun. Selain itu, terdapat Heritage seperti Padang lama daerah pondok, Mesjid Raya Ganting dan Museum Adityawarman. Seni pertunjukan seperti tari piring, tari payung, malam bagurau, tari pasambahan, tari galombang, saluang, dendang, randai, pencak silat, barongsai, perahu naga dan kuliner rendang yang terdapat dan diakui secara mendunia. Banyak pula pusat kerajinan yang menghasilkan pernak - pernik dari kota Padang (Pariwisata Kota Padang, 2012:1-12).

Pengenalan Kota Padang belum terolah dan dikemas secara baik. Hal tersebut menciptakan image yang kurang menarik bagi wisatawan, padahal sesungguhnya Kota Padang menyimpan potensi yang patut dibanggakan oleh masyarakatnya. Sebutan Padang sebagai kota bengkoang atau Padang is Your Motherland hanyalah sebutan tanpa pendalaman makna yang benar - benar menjadi brand dari kota Padang. Pada hakekatnya, jauh sebelum konsep City Branding dipublikasikan, banyak kota-kota di Indonesia yang memiliki positioning serta jati diri kuat dan positif cikal bakal sebuah branding. Contohnya, Pulau Bali disebut sebagai Pulau Dewata, Pulau Nirvana, Pulau Kamboja. Kota Bandung, selain disebut sebagai Kota Kembang, juga dikenal sebagai Paris Van Java (Diah (2005:13).

Menurut Chaniago, City Branding adalah proses atau usaha membentuk merk dari suatu kota untuk mempermudah pemilik kota tersebut untuk memperkenalkan kotanya kepada target pasar (investor, tourist, talent, event) kota tersebut dengan menggunakan kalimat positioning, slogan, icon, eksibisi, dan berbagai media lainnya. Sementara Pratikno, dosen Universitas Indonesia, 
mendefinisikan City Branding sebagai sebuah proses pengenalan sebuah kota yang diwakilkan pada icon, duta atau event yang diselenggarakan di kota (www.city branding.pdf. diakses pada tanggal 02 Januari 2013).

City branding merupakan sebuah magnitude luar biasa untuk mengembangkan kota sekaligus investasi, investor dan devisa, Seperti Singapura sebagai Negara kecil, tidak memiliki hasil bumi yang melimpah tetapi dalam perjalanannya menjadi Negara yang kaya. Negara Singapura menjadi primadona daerah kunjungan wisata. Bahkan saat ini, Negara tersebut sukses menanamkan citra-citra baru, seperti kota untuk sekolah atau kota untuk berobat, yang semuanya itu memenuhi ruang branding yang sengaja ditumbuhkan (Palupi, 2005:13). Sutanto (2005:15-16) menyatakan bahwa desain komunikasi visual senantiasa berhubungan dengan penampilan rupa yang dapat dicerap orang banyak dengan pikiran maupun perasaannya.

Menurut Teguh (1981: 1142), istilah komunikasi bersumber dari perkataan communis yang berarti: sama-sama, di sini maksudnya sama makna atau sama arti. Zubair (2006) menerangkan bahwa komunikasi adalah suatu proses pembentukan, penyampaian, penerimaan dan pengolahan pesan yang terjadi di dalam diri seseorang dan atau di antara dua atau lebih dengan tujuan tertentu. Definisi tersebut memberikan beberapa pengertian pokok yaitu komunikasi adalah suatu proses mengenai pembentukan, penyampaian, penerimaan dan pengolahan pesan.

Tidak hanya Singapura, fenomena City Branding kini memasuki hampir semua kota-kota besar di dunia. Tidak sedikit yang berhasil meraih sukses besar, seperti Malaysia, Hongkong, Taiwan, Dubai, Maroko, Meksiko, Cina, Thailand dan lainnya. Fenomena tersebut menjadi inspirasi dalam merancang City Branding Kota Padang.

Adapun faktor-faktor yang mempengaruhi suatu komunikasi adalah:

Komunikasi menimbulkan kesenangan yang menjadikan suatu hubungan hangat, akrab dan menyenangkan (2) Komunikasi mempengaruhi sikap, pendapat dan tindakan yang terjadi dengan menggunakan manipulasi psikologis (3) Hubungan social yang baik merupakan untuk menumbuhkan dan mempertahankan hubungan yang memuaskan dengan orang lain dalam hal interaksi dan asosiasi, serta (http://blogs.unpad.ac.id).

Fungsi komunikasi sebagaimana yang telah diringkas dari Harrol D. Loswell dalam Cangara (1998: 2-3) menjelaskan bahwa fungsi komunikasi adalah :

(1) Merupakan hasrat manusia untuk mengontrol lingkungannya, melalui komunikasi manusia dapat mengetahui suatu kejadian atau peristiwa, (2) Upaya manusia untuk dapat beradaptasi dengan lingkungannya, dalam lingkungan ini diperlukan penyesuaian agar manusia dapat hidup dalam suasana yang harmonis, dan (3 ) Upaya untuk melakukan transformasi warisan sosialisasi, maksudnya adalah suatu masyarakat yang ingin mempertahankan keberadaannya, maka anggota masyarakaktnya dituntut untuk melakukan pertukaran nilai, perilaku dan peranan.

\section{Konsep Penciptaam}

Adapun konsep Rancangan City Branding Kota Padang adalah Tangible \& Intangible Heritage yang dimunculkan melalui konsep verbal 
dan konsep visual. Konsep verbal City Branding Kota Padang menggunakan kata-kata yang simple namun memberikan kesan bermakna sehingga image yang diharapkan sampai kepada khalayak. Kata-kata (Tag Line) yang digunakan adalah visual yang akan dimunculkan adalah visualisasi dalam berbagai unsur dan elemen seperti warna dan tipografi. Visualisasi digabungkan sehingga semua unsur tersebut dikemas dalam bentuk yang lebih menarik seperti gambar berikut :

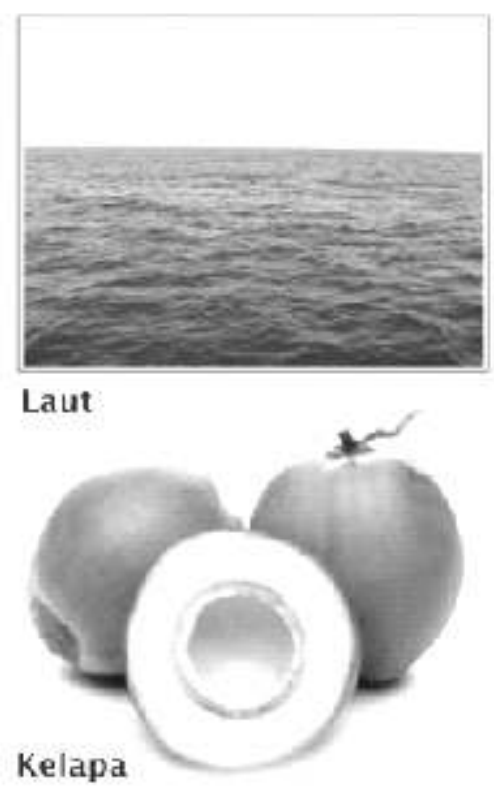

Gambar 1. Laut, Kelapa \& Marawa Sumber : www.padang.go.id

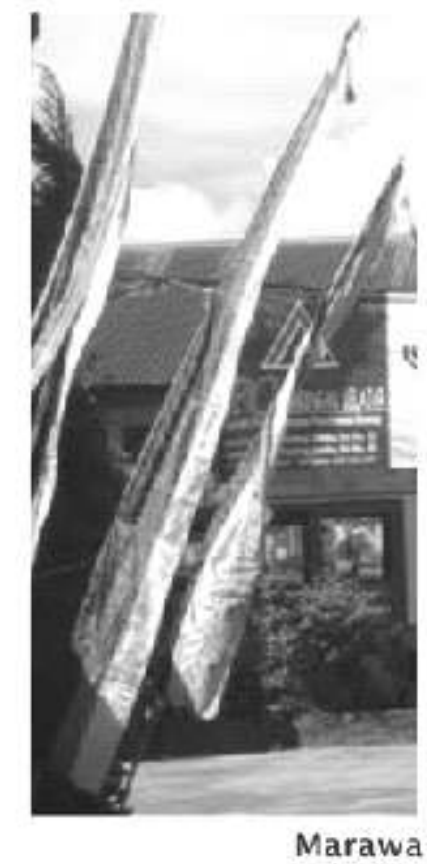

dalam bahasa Inggris yaitu "Tangible \& Intangible Heritage" yang artinya warisan budaya yang berwujud dan tidak berwujud (bendawi dan non bendwi). Kata yang dipilih mudah diartikan dan dipahami sesuai dengan kehidupan sehari-hari. Tagline yang dimunculkan tersebut sudah dapat mewakili Kota Padang secara keseluruhan, sehingga simple nya sebuah desain dan keindahan estetika sebuah desain dapat terjaga dengan baik. Adapun sumber acuan pada konsep rancangan kali ini sebagai referensi adalah Karya Handayani yang berjudul Solo - The Spirit of Java, tahun 2010.

Bahasa yang digunakan untuk Tagline adalah bahasa Inggris, tetapi untuk informasi lainnya tetap menggunakan bahasa Indonesia karena pada umumnya target audience domestik dan masyarakat umum. Adapun bentuk konsep
Warna yang di pakai pada rancangan kali adalah warna yang mendukung tema perancangan. Terdapat beberapa unsur, yaitu warna merah, kuning, hitam, biru dan hijau. Warna Merah, kuning, hitam merupakan gambaran dari marawa yang merupakan identitas orang Minangkabau dan warna ini melambangkan keberanian, semangat dan tahan tapo (tahan uji). Warna biru merupakan gambaran dari laut, biru juga memiliki pengaruh yang tenang dan mendalam.

Warna hijau merupakan gambaran kelapa. Warna hijau juga terinspirasi dari daun kelapa. Warna tersebut digunakan sebagai elemen dari budaya yang memiliki kesan alami, sehat dan nyaman. Unsur tersebut akan digabungkan sehingga memberikan kesan simple, menarik dan mudah diingat serta dipahami. Warna-warna 
tersebut merupakan deskripsi dari Kota Padang secara utuh.

Adapun tipografi yang yang dipakai adalah typeface yang cenderung simple dan modern, santai dan tidak terlalu tebal. Pemilihan tersebut berdasarkan dari dampak yang ditimbulkan dari jenis-jenis typeface tersebut serta hubungannya dengan produk itu sendiri. Kesan yang ingin ditampilkan adalah kesan serius tetapi tetap santai dan ceria. Dengan bantuan sedikit manipulasi huruf atau dikenal dengan imitasi huruf, diharapkan dapat menunjang image dari produk baik secara visual maupun perasaan. Adapun visual yang ditampilkan mengarah pada penonjolan foto dan tag line. Penggunaan foto ukuran. Image yang ingin ditujukan adalah Kota Padang yang berkesan menyenangkan dan menarik.

\section{Teori City Branding}

\section{City Branding}

Menurut Kawaratzis (2007) City Branding setidaknya terdapat dua aspek/dimensi yang harus dikomunikasikan kepada berbagai pihak. Kedua aspek/dimensi ini hendaknya bersifat komprehensif, integratif dan terpadu untuk mendukung image sebuah kota/wilayah menjadi lebih baik dan berdaya saing. Selengkapnya dapat dilihat pada gambar di bawah ini :

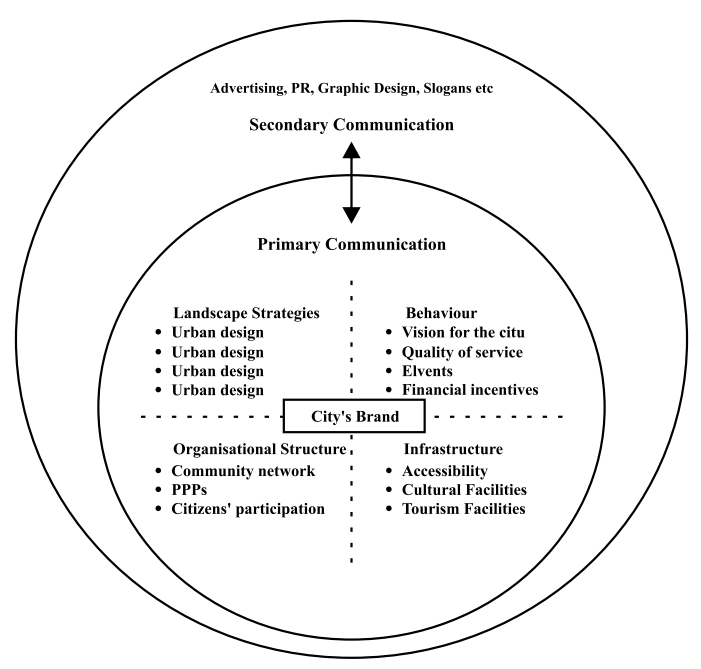

Gambar 2. Dua Aspek Komunikasi City Branding Sumber : Mukhtiali, 2010

dilandasi atas dasar sebuah foto audience nya. Kekuatan penggunaan Foto juga dapat mewakili kota secara keseluruhan dan image yang dihasilkan juga lebih kuat ditambah dengan penggunaan kata-kata. Sedangkan untuk gaya desain, lebih bersifat aktif, dinamis, tetapi tetap ada kesan eksklusifnya. Penerapan logonya nanti lebih bersifat pada gaya-gaya simple. Gaya desain ini didukung dengan unsur visual yang banyak menggunakan foto, jenis foto, teks dan variasi
Aspek/dimensi pokok dari komunikasi City Branding (primary communication), terdiri dari 4 aspek utama, yaitu berupa landscape strategies (urban design,public space, public art), behaviour (visi kota, events, kualitas layanan), organisational (Pubic Private Partnership) dan infrastruktur. Sementara dimensi/aspek kedua adalah berupa publikasi dan periklanan, public relation, desain dan slogan. Teori City Branding ini dipilih karena lebih 
mendekati pada rancanngan City Branding Kota Padang. Kota Padang masih didalam tahapan pengenalan sebuah kota melalui keunikan yang dikemas secara menarik nantinya. Proses atau tahapan dalam melakukan rancangan pengembangan sebuah kota dengan cara membangun image terhadap kota tersebut dan ini bisa dijadikan landasan dalam membangun City Branding Kota Padang karena terdapat proses dan pencitraan Kota didalam pemaparannya.

\section{Teori Brand \& Branding}

Brand menurut Surya (2003:15) adalah merek yang dimiliki oleh perusahaan, sedangkan branding adalah kumpulan kegiatan komunikasi yang dilakukan oleh perusahaan dalam rangka proses membangun dan membesarkan brand. Tanpa dilakukannya kegiatan komunikasi kepada konsumen yang disusun dan direncanakan dengan baik, maka sebuah merek tidak akan dikenal dan tidak mempunyai arti apa-apa bagi konsumen atau target konsumennya. Tanpa dilakukannya kegiatan komunikasi kepada konsumen yang disusun dan direncanakan dengan baik, maka sebuah merek tidak akan dikenal dan tidak mempunyai arti apa-apa bagi konsumen atau target konsumennya.

Brand memiliki pengaruh yang sangat kuat, mulai dari visual, baik itu warna maupun Tagline. Dalam pengenalannya sebuah brand kepada khalayak, yang paling penting itu adalah komunikatif. Pesan akan sampai jika dilakukan secara berulang-ulang dan melibatkan banyak orang dalam pengenalannya. Media juga menentukan kesuksesan dam pengenalan dan penanaman sebuah brand dibenak masyarakat. Oleh karena itu, rancangan City Branding kali ini lebih ditekankan kepada strategi brand melalui permainan warna dan tagline yang komunikatif.

\section{Teori Komunikasi}

Komunikasi merupakan interaksi manusia yang meliputi segala bentuk, baik bentuk pengumuman-pengumuman, maupun bentuk pernyataan individu-individu. Pengertian komunikasi secara etimologis berasal dari perkataan “communicatio". Selanjutnya, proses komunikasi pada umumnya dilakukan secara berurutan, dalam pemberian pesan artinya pesan menciptakan ide atau gagasan yang akan dikomunikasikan. Pesan yang telah terbentuk ini kemudian disampaikan kepada orang lain, baik secara langsung maupun tidak langsung. Cangara (1998:21-26) menjelaskan unsur-unsur komunikasi, antara lain:

(a) Sumber artinya semua peristiwa komunikasi akan melibatkan sumber sebagai pembuat atau pengirim informasi, (b) Pesan artinya sesuatu yang disampaikan pengirim kepada penerima, (c) Media ialah alat yang digunakan untuk memindahkana pesan dari sumber kepada penerima, (d) Penerima adalah pihak yang menjadi sasaran pesan yang dikirim oleh sumber, (e) Pengaruh atau efek adalah perbedaan antara apa yang dipikirkan, dirasakan dan dilakukan oleh penerima sebelum dan sesudah penerima pesan, (f) Tanggapan balik dapat berasal dari unsur seperti pesan dan media, meski pesan belum sampai pada penerima, dan (g) Lingkungan atau situasi ialah faktor-faktor tertentu yang dapat mempengaruhi jalannya komunikasi. Faktor ini dapat digolongkan atas lingkungan fisik, lingkungan sosial budaya, lingkungan psikologis dan dimensi waktu.

Penjelasan di atas diketahui bahwa setiap pelaku komunikasi akan melakukan empat tindakan yakni membentuk, komunikator atau menyampaikan, komunikan atau menerima, dan 
mengolah pesan. Keempat tindakan tersebut lazimnya terjadi secara berurutan. Membentuk pesan artinya menciptakan sesuatu ide atau gagasan. Ini terjadi dalam benak kepala seseorang melalui proses kerja sistem saraf. Pesan yang telah terbentuk ini kemudian disampaikan kepada orang lain. Baik secara langsung ataupun tidak langsung. Bentuk dan mengirim pesan, seseorang akan menerima pesan yang disampaikan oleh orang lain. Pesan yang diterima ini kemudian akan diolah melalui sistem saraf dan diinterpretasikan. Setelah diinterpretasikan, pesan tersebut dapat menimbulkan tanggapan atau reaksi dari orang tersebut. Apabila ini terjadi, maka orang tersebut kembali akan membentuk dan menyampaikan pesan baru. Demikianlah keempat tindakan ini akan terus-menerus terjadi secara berulang-ulang.

Komunikasi termasuk membentuk perubahan secara psikologis misalnya persepsi, sikap dan pendapat. Keberhasilan suatu komunikasi merupakan elemen yang terdapat dalam komunikasi tersebut. Hal-hal yang dapat mempengaruhi dalam proses komunikasi adalah aktifitas, konsep, minat, dan lain sebagainya. Cangara (1998:163) menjelaskan bahwa pengaruh komunikasi bisa terjadi dalam perubahan pengetahuan (knowledge), sikap (attitude) dan perilaku (behavior).

Dari penjelasan diatas dapat disimpulkan bahwa keberhasilan suatu komunikasi dipengaruhi oleh aktivitas, konsep dan minat. Selain itu komunikasi juga membentuk perubahan secara psikologis yaitu menimbulkan kesenangan, mempengaruhi sikap, hubungan sosial yang baik, serta menanamkan pengertian. Komunikasi juga memiliki peranan penting dalam sebuah rancangan City Branding, karena sampai atau tidaknya informasi sebuah kota dipengaruhi oleh peranan komunikasi yang efektif dan efisien.

\section{Teori Desain}

Desain adalah bagian dari seni, desain terdiri dari proses, menata/melayout, memperindah sesuai dengan kehendak seseorang yang terkadang dituntut untuk membuat sesuatu yang diinginkan oleh kliennya (http://id.88db.com).

Acher, Alexander dan Jones menyatakan bahwa: (a) Desain merupakan pemecahan masalah dengan satu target yang jelas, (b) Desain merupakan temuan unsur fisik yang paling objektif atau, (c) Desain adalah tindakan dan inisiatif untuk mengubah karya manusia.

Selanjutnya Menurut The American College Dictionary desain adalah : menyiapkan rencana pendahuluan atau perancangan, membentuk atau memikirkan sesuatu di dalam benak kita; merancang 'rencana', menetapkan dalam fikiran; tujuan; maksud, garis besar, sketsa; rencana, seperti dalam kegiatan seni, bangunan, gagasan tentang mesin yang akan diwujudkan, merencanakan dan memberi sentuhan artistik yang dikerjakan dengan kepakaran yang tinggi, pelbagai detil gambar, bangunan; wahana lainnya untuk pekerjaan artistic, serta merupakan pekerjaan artistik (http://Kajian Teori Desain).

Di dalam Encyclopedia of The Art desain adalah dorongan keindahan yang diwujudkan dalam suatu bentuk komposisi; rencana komposisi; sesuatu yang memiliki kekhasan; atau garis besar suatu komposisi, misalnya bentuk yang berirama, desain motif, komposisi nada dan lainlain. Sedangkan menurut Everyman's Encyclopedia desain adalah panduan untuk menyelesaikan gambar; susunan yang digunakan untuk melengkapi karya secara keseluruhan; kelayakan penempatan bahan-bahan dalam sebuah karya (http://Kajian Teori Desain).

Menurut Kusrianto (2006:30) terdapat 
beberapa unsur-unsur visual, antara lain:

(a) Garis (line) adalah unsur desain yang menghubungkan antara satu titik poin dengan titik poin yang lain sehingga bisa berbentuk gambar garis lengkung (curve) atau lurus (straight) (b) Bentuk (shape) adalah segala hal yang memiliki diameter tinggi dan lebar. Bentuk dasar yang dikenal orang adalah kotak (rectangle), lingkaran (circle), dan segitiga (triangle) (c) Tekstur (texture) adalah tampilan permukaan (corak) dari suatu benda yang dapat dinilai dengan cara dilihat atau diraba. Pada prakteknya, tekstur sering dikategorikan sebagai corak dari suatu permukaan benda, misalnya permukaan karpet, baju, kulit kayu, dan lain sebagainya (d) Ruang (space) merupakan jarak antara suatu bentuk dengan bentuk lainnya yang pada praktek desain dapat dijadikan unsur untuk memberi efek estetika desain. (e) Warna (color)merupakan unsur penting dalam obyek desain

Prinsip dasar sebuah desain merupakan pengorganisasian unsur-unsur dasar desain dengan memperhatikan prinsip-prinsip dalam menciptakan dan mengaplikasikan kreatifitas. Pengorganisasian tersebut dimunculkan dalam sebuah desain komunikasi visual. Frank Jefkins (1997:245-246) mengelompokkan prinsip-prinsip desain menjadi

(a) Kesatuan (unity) merupakan sebuah upaya untuk menggabungkan unsur-unsur desain menjadi suatu bentuk yang proporsional dan menyatu satu sama lain ke dalam sebuah media. (b) Keberagaman (variety) bertujuan untuk menghindari suatu desain yang monoton. Untuk itu diperlukan sebuah perubahan dan pengkontrasan yang sesuai. Adanya perbedaan besar kecil, tebal tipis pada huruf, pemanfaatan pada gambar, perbedaan warna yang serasi, dan keragaman unsur-unsur lain yang serasi akan menimbulkan variasi yang harmonis, (c) Keseimbangan (balance) adalah bagaimana cara mengatur unsur-unsur yang ada menjadi sebuah komposisi yang tidak berat sebelah. (d) Ritme/ irama (rhythm) adalah suatu gerak yang dijadikan sebagai dasar suatu irama dan ciri khasnya terletak pada pengulanganpengulangan yang dilakukan secara teratur yang diberi tekanan atau aksen. (e) Penekanan (emphasis) dalam desain merupakan hal yang penting untuk menghindari kesan monoton

Desain merupakan sebuah solusi dam mewujudkan sebuah visualisasi. Sangat banyak yang perlu dipertimbangkan dalam mengemas desain yang menarik. Teori desain ini dipakai guna melengkapi kesempurnaan dalam rancangan City Branding Kota Padang. Melalui tahapan desain akan lahir visualisasi yang baik dan menarik.

\section{Teori warna}

Warna (color) merupakan unsur penting dalam obyek desain. Warna yang tepat akan mengasilkan desain yang baik. Rustan (2013:36) menjelaskan, makna dari warna yaitu :

(a) Merah melambangkan kesan energi, kekuatan, hasrat, erotisme, keberanian, pencapaian tujuan, resiko, ketenaran, perjuangan, perhatian. (b) Putih menunjukkan kedamaian, permohonan maaf, pencapaian diri, spiritualitas, kesederhanaan, kesempurnaan, kebersihan, cahaya,keamanan, persatuan. (c) Hitam melambangkan perlindungan, mengikat, kekuatan, formalitas, perasaan yang dalam, harga diri, anti kemapanan dsb. (d) Biru memberikan kesan komunikasi, peruntungan yang baik, 
kebijakan, perlindungan,tenang, kelembutan, dinamis, kreativitas, kedamaian, kepercayaan, loyalitas, kekuatan dari dalam, kestabilan, kesadaran, pesan, ide, berbagi, idealisme, persahabatan dan harmoni, kasih sayang. (e) Hijau menunjukkan kesuburan, pertumbuhan, kesuksesan materi, pembaharuan, daya tahan, keseimbangan, dan persahabatan. (f) Kuning merujuk pada matahari, ingatan, imajinasi logis, energi sosial, kerjasama, kebahagiaan, kegembiraan, kehangatan, loyalitas, persepsi, pemahaman, kebijaksanaan, kecemburuan, optimisme. (g) Warna Merah Muda menunjukkan simbol kasih sayang dan cinta, persahabatan, feminin, kepercayaan, niat baik, pengobatan emosi, damai, perasaan yang halus, perasaan yang manis dan indah, (h) (http:// teori warna.com)

$\mathrm{S}$ e m e n t a r a i t u, d a 1 a m http://marawanews.com menjelaskan makna dari marawa, Hitam Melambangkan tahan tapo serta mempunyai akal dan budi dengan kebesaran Luhak Limopuluah. Merah Melambangkan keberanian punya raso jo pareso dengan kebesaran Luhak Agam. Kuning Melambangkan keagungan, punya undang-undang dan hukum dengan kebesaran Luhak Tanahdata.

Pada rancangan City Branding kali ini, warna yang dipakai adalah warna yang sesuai dengan identitas kan karakteristik Kota Padang. Penetapan warna didapatkan dari hasil pencarian identitas dari Kota Padang yang ditempuh melalui observasi \& pemotretan sumber dilapangan. Penggunaan warna selain sebagai identitas juga sebagai daya tarik bagi masyarakat serta wisatawan. Warna juga merupakan bagian yang mewakili ekspresi. Filosofi warna merupakan sebuah deskripsi atau gambaran dari Kota Padang itu sendiri.

\section{Kesimpulan}

City Branding sebagai sebuah proses dan usaha membentuk merk dari sebuah kota untuk mempermudah pemilik kota tersebut untuk memperkenalkan kota tersebut kepada masyarakat luas. Pengenalan sebuah kota dapat ditempuh melalui kalimat positioning, slogan, icon, eksebisi dan berbagai media yang dianggap efektif dan efisien. Pemilihan media juga dilakukan berdasarkan data yang ditemukan dan permasalahan yang terdapat pada kota tersebut..

Sesuai dengan tujuan dalam rancangan ini adalah Merancang komunikasi visual untuk memperkenalkan Kota Padang sebagai kota tujuan wisata yang memiliki keanekaragaman objek wisata, heritage, makanan, serta handycraft yang menarik. Dalam proses dan perjalanan dalam pengemasan selama merancang, kesulitan mendapatkan data \& informasi menjadi pengalaman tersendiri sehingga perancang lebih banyak memiliki tantangan dan terus berusaha untuk dapat mewujudkan karya rancangan City Branding Kota Padang.

Untuk mewujudkan City Branding Kota Padang, disarankan supaya lebih disiplin dalam mengelolah setiap infrastruktur ataupun segala sesuatu yang menjadi aset kota Padang baik itu masyarakat maupun pemerintah setempat. Apa yang dimiliki oleh kota Padang belum tentu dimiliki oleh kota lain. Semua yang ada di kota Padang pada hakekatnya bisa menjadi daya tarik sendiri bagi wisatawan ataupun orng-orang yang berkunjung ke Padang. Semakin ramai orang berkunjung ke Kota Padang, maka juga akan semakin dikenal Kota tersebut.

Kepada seluruh infrastruktur di Kota Padang, supaya dapat bersama-sama peduli terhadap Kota Padang. Peran penting besarnya sebuah kota salah satunya adalah dari 
masyarakatnya. Mari kita sama-sama mendukung program pemerintah dalam pengembangan kota yang lebih baik dan mari kita sama menjaga semua yang ada di kota Padang. Kepada pemerintah tata kota ataupun Dinas Pariwisata dapat bekerjasama dalam memberikan informasi tentang Kota Padang sehingga tujuan akhir dari City Branding dapat tercapai dan dieksekusikan secara utuh.

Kepada rekan-rekan akademis, supaya tak henti-hentinya berkarya serta mulai mengembangkan pikiran untuk Kota Padang. Mudah-mudahan dapat memberikan sumbang pikiran untuk kemajuan kota Padang. Siapapun kita, selagi masih berada di Kota Padang berarti kita bertanggung jawab juga terhadap perkembangan kota.

Kepada para pelaku usaha ekonomi kreatif, teruslah mengembangkan industry kreatif. Suatu saat nanti Kota Padang pasti akan besar dengan industry kreatifnya. Seluruh penjuru dunia pasti akan berbondong-bondong dataang, jika kota Padang di Branding dengan benar dalam industry kreatif. Dan semoga rancangan ini dapat di eksekusikan dan dipergunakan untuk Kota Padang. 


\section{Daftar Pustaka}

Cangara dalam http:/Kajian Teori Komunikasi /Asal Kata 1.htm, (online) di akses tanggal 20 Januari 2013.

http://palantaminang.wordpress.com/2011/04/01/ marawa-minangkabau melambangkan keagungan-keberanian-dan-kesucian/ diakses tangggal 8 Mei 2013

Jefkins, Frank. 1999b. Prinsip dalam Desain Komunikasi Visual. Yogyakarta : Penerbit Andi

Kawaratzis, Mihalis dan Ashworth. 2007. "Marketing the City of Amsterdam". Cities: Vol 1.

Kusrianto, Agus (2007). Pengantar Desain Komunikasi Visual. Yogyakarta: Andi Offset.

Muktiali, Mohammad. 2012. Kaji banding city branding kota semarang dengan kota di Indonesia (solo \& surabaya) dan kota dunia (kota amsterdam). Solo : Karya Ilmiah

Palupi, Dyah Hasto. 2005. Ayo City branding. Jakarta: Gramedia

Rustan, Suryanto. 2013. Mendesain Logo. Jakarta : Gramedia

Surya dalam Muktiali, Mohammad. 2012. Kaji banding city branding kota semarang

dengan kota di Indonesia (solo \& surabaya) dan kota dunia (kota amsterdam). Solo : Karya

Teguh dalam http:/Kajian Teori Komunikasi /Asal Kata 1.htm, (online) di akses tanggal 20 Januari 2013.

Zubair dalam http:/Kajian Teori Komunikasi /Asal Kata 1.htm, (online) di akses tanggal 20 Januari 2013.

Buku Pariwisata Kota Padang 2012 